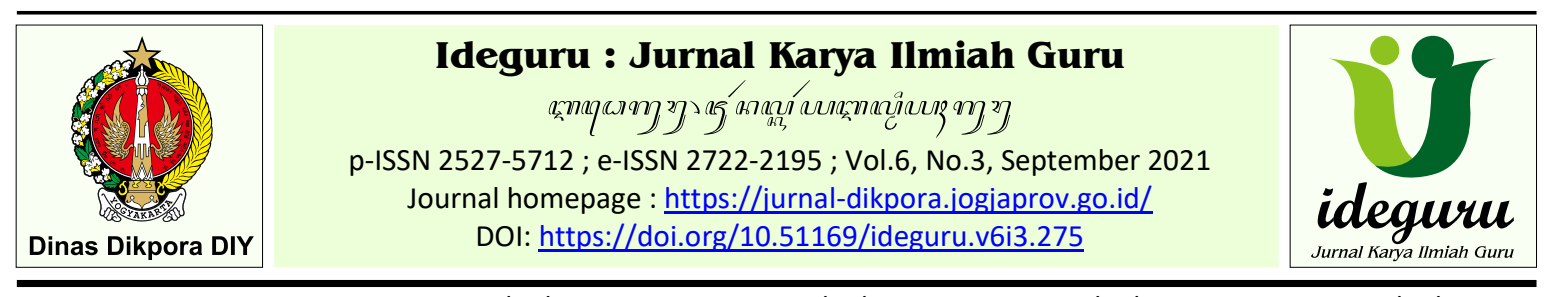

Artikel Penelitian - Naskah dikirim: 15/04/2021 - Selesai revisi: 24/05/2021 - Disetujui: 06/06/2021 - Diterbitkan: 01/09/2021

\title{
Metode Mentoring untuk Meningkatkan Kompetensi Guru dalam Pemantauan Karakter Siswa Berbasis Afeksi Selama PJJ
}

\author{
Fadiyah Suryani \\ SMA Negeri 5 Yogyakarta, Yogyakarta, Daerah Istimewa Yogyakarta, Indonesia \\ fadiyah.suryani16@gmail.com
}

\begin{abstract}
Abstrak: Tujuan penelitian ini untuk meningkatkan kompetensi guru dalam pemantauan karakter siswa berbasis program afeksi pada masa Pembelajaran Jarak Jauh (PJJ) dengan menggunakan metode mentoring. Subjek penelitian ini adalah guru SMAN 5 Yogyakarta yang mendapat tugas sebagai wali kelas X, XI dan XII. Metode penelitian yang digunakan yaitu penelitian tindakan sekolah yang dilaksanakan dalam bentuk siklus melalui empat tahapan, yaitu; perencanaan, pelaksanaan, observasi, dan refleksi. Pengumpulan data dilakukan melalui observasi, wawancara, angket dan dokumentasi. Analisis data dalam penelitian ini dilakukan dengan cara merefleksi hasil observasi terhadap proses pembimbingan mentor kepada mentee. Untuk memberikan makna keberhasilan tindakan digunakan kriteria yaitu tindakan dinyatakan berhasil apabila setelah tindakan ada peningkatan kompetensi guru dalam memantau karakter siswa berbasis program afeksi pada masa PJJ mencapai rata-rata minimal 80 dan kompetensi mentor dalam melaksanakan mentoring pemantauan karakter siswa berbasis program afeksi selama PJJ mencapai rata-rata minimal 90. Hasil analisis menunjukkan bahwa pemantauan karakter siswa berbasis program afeksi pada masa PJJ dengan menerapkan metode mentoring dapat meningkatkan kompetensi guru, yaitu kompetensi guru dalam pemantauan karakter siswa kelas X, XI dan XII oleh guru pada siklus I 67,1 dan pada siklus II sebesar 84,5 , kompetensi mentor dalam memahami metode mentoring pada siklus I 86 dan pada siklus II sebesar 92,5 dengan kategori amat baik.
\end{abstract}

Kata kunci: metode mentoring; kompetensi guru; karakter berbasis afeksi; pembelajaran jarak jauh.

\section{Mentoring Methods to Improve Teachers 'Competency in Afection-Based Student Character Monitoring During Distance Learning}

\begin{abstract}
The aim of this research is to improve teacher competence in monitoring student character based on affection programs during Distance Learning (PJJ) by using the mentoring method. The subjects of this study were teachers of SMAN 5 Yogyakarta who got the assignment as homeroom teacher for class $X, X I$ and XII. The research method used is school action research which is carried out in a cycle through four stages, namely; planning, implementation, observation, and reflection. Data collection was carried out through observation, interviews, questionnaires and documentation. Data analysis in this study was carried out by reflecting on the results of observations on the mentoring process of mentors to mentees. To give the meaning of the success of the action used criteria, namely the action is declared successful if after the action there is an increase in teacher competence in monitoring the character of students based on the affection program during the PJJ period reaches an average of at least 80 and the competence of the mentor in implementing mentoring monitoring of student character based on affection programs as long as PJJ reaches an average -a minimum of 90 . The results of the analysis show that monitoring the character of students based on the affection program during PJJ by applying the mentoring method can improve teacher competence, namely the competence of teachers in monitoring the character of students in grades X, XI and XII by teachers in cycle I 67.1 and in cycle II amounting to 84,5, mentor competence in understanding mentoring methods in cycle I 86 and cycle II amounted to 92.5 with very good category.
\end{abstract}

Keywords: mentoring method; teacher competence; affection-based character; distance learning.

\section{Pendahuluan}

Pendidikan karakter telah lama menjadi bagian dari pendidikan di SMAN 5 Yogyakarta. Pendidikan karakter di sekolah mendidik kebiasaan baik kepada siswa agar bersikap dan bertindak sesuai dengan nilai-nilai agama, budaya dan karakter bangsa. Pendidikan karakter dapat membantu siswa dalam mendidik etika, tanggung jawab, dan pengajaran karakter yang baik melalui nilai-nilai universal (Berkowitz \& Bier, 2005: 7). Budaya yang berkembang di sekolah merupakan bagian penting dalam pembentukan karakter siswa. Karakter akan 
terbentuk dari lingkungan, keluarga dan orangorang yang membentuknya.

Sistem penanaman nilai-nilai karakter pada seluruh warga sekolah terdiri dari komponen pengetahuan, kemauan, dan tindakan untuk melaksanakan nilai-nilai yang baik. Pendidikan karakter dapat dimaknai sebagai "the deliberateuse of all dimensions of school life fosteroptimal characterdevelopment" (Rohinah, 2012: 55). Penanaman nilai life skill harus ada dalam pendidikan afeksi di sekolah, walaupun tidak harus dalam bentuk mata pelajaran, tapi bisa terintegrasi dalam mata pelajaran tersebut. Bagian yang paling penting adalah bagaimana guru menanamkan nilai pada peserta didik melalui pendidikan afeksi yang diajarkan di sekolah (Bambang Irianto, 2003: 2).

Pemendikbud membuat kebijakan Penguatan Pendidikan Karakter (PPK), dengan tujuan untuk menumbuhkembangkan karakter yang baik kepada peserta didik. Ada lima nilai yang harus dikembangkan, yaitu (1) religius, (2) nasionalis, (3) integritas, (4) mandiri, dan (5) gotong royong. Lima karakter ini bisa dikembangkan oleh sekolah. Poerwadarminta menulis bahwa karakter adalah tabiat, watak, sifat-sifat kejiwaan, akhlak dan budi pekerti yang membedakan seseorang dengan orang lain. (Poerwadarminta, 2007, 521).

Thomas Lickona menyampaikan beberapa hal yang penting dalam pendidikan karakter, di antaranya: (1) Sebagian besar generasi muda saling melukai (2) Menyampaikan nilai-nilai moral pada generasi muda, (3) Sekolah sangat mempunyai kedudukan penting sebagai pendidik karakter ketika banyak peserta didik memperoleh hanya sedikit pendidikan moral dari orangtua, masyarakat, atau lingkungan lembaga keagamaan, (4) Nilai-nilai moral yang secara universal masih diterima, (5) Pendidikan moral membutuhkan demokrasi (6) Tidak ada sesuatu sebagai pendidikan bebas nilai. (7) Kesadaran dan keikhlasan guru sangat dibutuhkan dalam pendidikan karakter dan (8) Pendidikan karakter yang efektif akan menjadikan sekolah lebih berakhlak, dan memahami lingkungan (Lickona, Thomas, 1997: 91). Sembilan hal ini menunjukkan kalau pendidikan karakter sangat diperlukan, apalagi disaat pandemi corona melanda dunia, sehingga pengawasan terhadap anak-anak semakin sulit.

Mentoring berasal dari kata mentor yang mempunyai arti petunjuk jalan, tutor sebaya, teman pembimbing. Mentoring adalah suatu proses peralihan informan dari pengetahuan, sosial, modal dan dukungan psikologis yang dapat diterjemahkan oleh mentee (orang yang dimentoringi) (Sudarman Danim, 2011: 40). Kegiatan mentoring terdiri dari mentor dan mentee. Mentor sebagai penasehat dan mentee sebagai anggota mentoring. Ada beberapa fase dalam mentoring yaitu: 1) Fase persiapan (preparing); 2) Fase negosiasi (negotiating); 3) Fase kemungkinan (enabling); 4) Fase penutup (coming to closure) (DuBois dan Karche, 2005).

Mentor dapat melakukan beberapa tugas dalam proses pengamatan karakter siswa. Agar mentoring berjalan dengan baik, diperlukan kemampuan dalam hal komunikasi antarpribadi, antar kelompok, dan komunikasi massa (Edi Harapan dan Syawani Ahmad, 2014:12). Dengan adanya mentoring yang dilakukan terhadap guru di SMAN 5 Yogyakarta diharapkan dapat meningkatkan kompetensi guru dalam pemantauan karakter siswa. SMA Negeri 5 Yogyakarta adalah sekolah yang berbasis afeksi dan sudah melaksanakan pendidikan karakter.

Kondisi masa pandemi membuat semua kegiatan yang ada disekolah mengalami banyak perubahan, diantaranya pembelajaran di sekolah. Aktivitas sekolah dilaksanakan secara daring atau Pembelajaran Jarak Jauh (PJJ), pembelajaran yang dilakukan diluar lingkungan sekolah. Semua mata pelajaran mempunyai nilai-nilai karakter yang harus dikembangkan dalam pendidikan di sekolah maupun diluar sekolah, direalisasika dan dihubungkan dengan kehidupan sehari-hari. Sehingga pembelajaran nilai-nilai karakter diharapkan dapat menyentuh dalam diri setiap peserta didik, serta dapat bermanfaat dalam aktivitas peserta didik seharihari di lingkungan sekolah maupun di luar sekolah. Selama Pembelajaran Jarak Jauh (PJJ) guru kesulitan untuk memantau karakter siswa. Dari hasil angket dengan guru mata pelajaran, ada $80 \%$ guru kesulitan dalam memantau karakter siswa untuk penilaian afeksi. Maka dicari cara yang terbaik untuk memantau karakter siswa dengan program afeksi secara PJJ dengan metode mentoring untuk guru-guru mata pelajaran.

Afeksi diterjemahkan sebagai nilai - nilai luhur yang harus dimiliki oleh semua warga sekolah. Ada 5 (lima) nilai - nilai luhur yang menjadi kesepakatan warga SMA Negeri 5 Yogyakarta yang disebut dengan 5 Habits puspanegara, yaitu: 1) Religius/Beriman dan bertakwa; 2) Jujur; 3) Peduli; 4) Toleransi; 5) Disiplin.

Dari masalah-masalah di atas dapat dibuat rumusan masalah penelitian tindakan sekolah ini adalah: 1) Apakah penerapan metode mentoring 
dapat meningkatan kompetensi guru dalam pemantauan karakter siswa berbasis program afeksi pada masa PJJ di SMAN 5 Yogyakarta tahun 2021?; 2) Bagaimana penerapan metode mentoring yang dapat meningkatkan kompetensi guru dalam pemantauan karakter siswa berbasis program afeksi pada masa PJJ di SMAN 5 Yogyakarta tahun 2021?

Tujuan penelitian untuk: 1) Meningkatkan kompetensi guru dalam pemantauan karakter siswa berbasis program afeksi pada masa PJJ di SMAN 5 Yogyakarta tahun 2021dengan menerapkan metode mentoring. 2) Mendiskripsikan penerapan metode mentoring untuk meningkatkan kompetensi guru dalam pemantauan karakter siswa berbasis program afeksi pada masa PJJ di SMAN 5 Yogyakarta tahun 2021.

Manfaat penelitian ini adalah sebagai berikut: 1) Bagi sekolah: a) Menyampaikan bahwa metode metoring dapat meningkatkan penguatan karakter siswa berbasis program afeksi pada masa PJJ; b) Meningkatkan budaya akademik dalam lingkungan sekolah sehingga bisa melakanakan perbaikan mutu pembelajaran dan pendidikan karakter peserta didik pada masa PJJ; 2) Bagi Kepala Sekolah dan peneliti selanjutnya untuk mendorong Kepala Sekolah melaksanakan pembimbingan guru dengan penerapan metode mentoring untuk penguatan pendidikan karakter pada masa PJJ; 3) Bagi Guru untuk meningkatkan kompetensi guru dalam memberikan penguatan Pendidikan karakter pada siswa; 4) Bagi siswa, kegiatan karakter siswa akan terpantau walaupun siswa berada di rumah.

\section{Metode Penelitian}

Penelitian ini menggunakan penelitian tindakan yang terfokus pada aktivitas yang ada sekolah sehingga penelitiannya berupa Penelitian Tindakan Sekolah. Dalam penelitian ini peneliti dibantu oleh seorang kolaborator yaitu wakil kepala sekolah urusan afeksi bapak Drs. Muhammad Junaidi Sakir, M.Pd. Penelitian akan dilaksanakan di SMAN 5 Yogyakarta yang berlokasi di Jalan Nyi Pembayun no. 39 Kotagede Yogyakarta. SMAN 5 Yogyakarta mempunyai rombongan 24 kelas yang terdiri dari kelas $\mathrm{X}$ ada 8 kelas, kelas XI ada 8 kelas dan kelas XII ada 8 kelas. Sekolah terkenal dengan brand sekolah berbasis afeksi.

Penelitan Tindakan Sekolah ini dilaksanakan pada bulan Januari sampai April 2021. Penentuan waktu berdasarkan pertimbangan bahwa pembelajaran semester 2 dilaksanakan pada bulan Januari. Sehingga pemantauan penguatan karakter siswa oleh guru dan wali kelas bisa dilaksanakan selama Pembelajaran Jarak Jauh (PJJ). Subjek penelitian terdiri dari guru-guru SMAN 5 Yogyakarta yang mendapat tugas sebagai wali kelas X, XI dan XII terdiri dari 24 wali kelas.

Penelitian ini dilaksanakan menggunakan metode Penelitian Tindakan Sekolah dalam tahapan bersiklus. Masing-masing siklus terdiri dari 2 pertemuan. Dalam melakasanakan penelitian mengacu pada model Kemmis dan Taggart (2000) yang mengembangkan suatu konsep penelitian tindakan dengan menggunakan model spiral yang terdiri dari empat tahap:1) Tahap perencanaan (planning), 2) Tahap pelaksanaan (acting), 3) Tahap pengamatan (observing) dan 4) Tahap merefleksi (reflection).

Penelitian ini dilakukan dalam 2 siklus. Dalam perencanaan peneliti memutuskan apabila hasil pada siklus ke dua memenuhi indikator keberhasilan maka penelitian akan dihentikan. Namun apabila hasil siklus ke dua belum memenuhi indikator keberhasilan maka tindakan akan dilajutkan lagi sampai terpenuhi indikator keberhasilan.

Penelitian ini berasal dari sumber data primer dan sumber data sekunder (Arikunto, 2010: 107). Sumber data primer dari guru SMAN 5 Yogyakarta yang dapat memberikan informasi tentang data penelitian. Sumber data primer terdiri dari: 1) Hasil angket evaluasi diri terhadap kompetensi guru oleh mentor dan peneliti; 2) Hasil pengamatan terhadap pemantauan penguatan karakter siswa oleh guru guru dalam proses pembelajaran; 3) Hasil pengamatan mentoring terhadap guru oleh tim afeksi dan peneliti; 4) Hasil observasi langkah mentoring oleh kolaborator; 5) Hasil angket penguatan karakter siswa; 6) Angket penanaman karakter siswa; 7) Foto-foto. Sumber data sekunder adalah data yang tidak langsung diberikan kepada pengumpul data. Sumber data sekunder terdiri dari: 1) Daftar hadir peserta bimbingan mentor; 2) Daftar hadir mentee; 3) Dokumen hasil goole form.

Pengumpulan data menggunakan instrumen penelitian supaya dalam menganalisis data lebih mudah dan lebih baik hasilnya. Instrumen yang digunakan dalam penelitian ini yaitu: 1) Angket evaluasi diri terhadap kompetensi pedagogik guru dalam penguatan karakter siswa; 2) Lembar pengamatan terhadap guru dalam proses mentoring oleh mentor; 3) Lembar pengamatan terhadap guru dalam penguatan karakter siswa di kelas; 4) Angket kemampuan guru dalam penguatan karakter siswa dengan program afeksi 
selama PJJ; 5) Angket guru terhadap mentor; 6) Lembar observasi setiap langkah pada metode mentoring

Teknik pengumpulan data yang digunakan adalah: 1) Observasi; 2) Wawancara; 3) Angket; 4) Dokumentasi. Penelitian ini menggunakan analisis data kualitatif model mengalir dari Miles dan Huberman yang meliputi tiga hal ( Siswono, 2008: 29) yaitu: 1) Reduksi data; 2) Penyajian data; 3) Penarikan kesimpulan. Indikator keberhasilan metode mentoring adalah: 1) Kompetensi guru dalam memantau karakter siswa berbasis program afeksi selama PJJ mencapai rata-rata minimal $80 ; 2$ ) Kompetensi mentor dalam melaksanakan mentoring pemantauan karakter siswa berbasis program afeksi selama PJJ mencapai rata-rata minimal 90.

\section{Hasil dan Pembahasan}

Penelitian ini diawali dari sulitnya memantau karakter siswa oleh guru dan wali kelas selama Pembelajaran Jarak Jauh (PJJ). Peneliti melaksanakan pertemuan dengan wali kelas yang kesulitan dalam memantau karakter siswa selama PJJ karena pandemi covid-19, pada hari Selasa, 12 Januari 2021 di ruang Lab Seni dan Budaya SMA N 5 Yogyakarta. Pertemuan ini membahas tentang kesulitan wali kelas dalam memantau karakter siswa selama PJJ. Selanjutnya diadakan pertemuan dengan 8 guru yang bertugas membantu peneliti dalam membantu ketugasan guru untuk memantau karakter siswa.

Guru yang membantu peneliti ini disebut sebagai mentor yang sudah punya pengalaman dalam membuat program kegiatan selama PJJ. Karena ada 24 kelas maka jumlah wali kelas ada 24 guru yang disebut sebagai mentee. Guru yang akan ikut dalam kegiatan mentoring sebanyak 24 guru maka peneliti mengajak 8 guru untuk membantu bimbingan yang disebut mentor ditambah peneliti sehingga semuanya ada 9 mentor. Mentor akan membantu 24 mentee dalam penguatan karakter siswa selama PJJ. Penugasan 9 Mentor untuk kelas X, XI dan XII, masing-masing terdiri dari 3 mentor. Satu mentee menangani 1 kelas sesuai dengan siswa ampuannya.

\section{Hasil Penelitian}

Sesuai dengan rancangan yang disusun, penelitian tindakan sekolah dilaksanakan 2 (dua) siklus, masing-masing siklus dilaksanakan dua kali pertemuan.

\section{Siklus 1}

Pertemuan pertama siklus I dilaksanakan pada hari Senin tanggal 18 Januari 2021 di ruang
Lab Seni Budaya SMAN 5 Yogyakarta pukul 13.00 - 15.00 WIB. Pelaksanaan kegiatan yaitu menerapkan tindakan sesuai dengan skenario dan Rencana Pelaksanaan Pembimbingan. Fase pertama mentoring dimulai dengan fase persiapan (Preparing), keadaan awal kegiatan untuk mencapai hubungan yang baik antara mentor dan mentee dan diutamakan pada persiapan mentor untuk tugas baru dan persiapan memulai kerjasama dengan mentee. Pada tahap ini tugas mentor adalah a) Mengidentifikasi masalah-masalah yang dihadapi wali kelas pada saat pemantauan; b) Memberi motivasi pada mentee tentang ketugasannya; c) Jadi role mode dengan memberi contoh perilaku mentor pada mentee; d) Menyampaikan tujuan metode mentoring kepada mentee; e) Menyampaikan langkah-langka mentoring.

Peneliti memberikan materi mentoring dan langkah-langkah mentoring pada mentor, menyusun rencana untuk metode mentoring. Diskusi membahas masalah karakter siswa dalam program afeksi, mencari solusi yang tepat untuk memantau karakter siswa oleh wali kelas. Mentor mengisi angket tentang pemahaman mentor terhadap metode mentoring yang akan dilaksanakan.

Kolaborator mengamati kegiatan siklus I pertemuan pertama dengan mengisi lembar observasi. Dari hasil pengamatan kolaborator tahap pertama mentoring yaitu tahap persiapan (Preparing) sudah sesuai dengan langkahlangkah pada skenario penelitian mentoring.

Pertemuan kedua siklus I dilaksanakan pada hari Senin tanggal 25 Januari 2021 di Lab Seni Budaya SMA N 5 Yogyakarta pukul 13.00 s.d 15.00 WIB. Pertemuan kedua untuk fase mentoring adalah fase negosiasi (negotiating) dengan langkah mentoring, pada fase ini mentee terlibat bersama dengan mentor dan terjadi interaksi antara mentor dan mentee untuk menentukan waktu untuk melaksanakan mentoring.

Mentor menyampaikan langkah-langkah metode mentoring pada masa PJJ kepada mentee. Mentee mengisi kartu identifikasi masalah karakter siswa selama PJJ dan mendiskusikan masalah ini dengan mentor dalam upaya mencari solusi yang terbaik dalam memantau karakter siswa. Mentor menyampaikan tentang program afeksi sekolah yang harus dipahami oleh mentee. Mentor akan masuk dalam group WA kelas jika akan memantau kegiatan mentee. Mentor akan membantu mentee jika mendapat kesulitan.

Mentee mengisi kartu indintifikasi masalah karakter siswa selama PJJ pada minggu pertama dan minggu kedua bulan Januari pada semester 
2. Kartu permasalahan tersebut di diskusikan dengan mentor sesuai jenjang kelas masingmasing.

Kolaborator mengamati kegiatan siklus I pertemuan kedua dengan mengisi lembar observasi kegiatan selama pertemuan. Dari hasil pengamatan kolaborator tahap kedua mentoring yaitu tahap negosiasi (negotiating) sudah sesuai dengan langkah-langkah pada skenario penelitian mentoring.

Observasi terhadap proses mentoring dilakukan bersamaan dengan pelaksanaan tindakan. Untuk mendapatkan data yang diperlukan kolaborator menggunakan instrumen yang telah disiapkan pada tahap perencanaan. Guna mengukur keberhasilan mentee dalam memantau penguatan karakter siswa dengan program afeksi selama PJJ menggunakan angket lembar observasi.

Dalam tahap refleksi, peneliti sebagai salah satu mentor bersama dengan mentor yang lain dan kolaborator melaksanakan evaluasi tindakan yang telah dilaksanakan yang terdiridari evaluasi mutu dari tindakan yang dilaksankan. Dari hasil kajian diperoleh kesimpulan sebagai berikut:1) Pemantauan karakter toleransi dan karakter peduli lebih sulit daripada karakter yang lain; 2) meningkatkan penguasaan mentee dalam merekap hasil dari google from. Hasil evaluasi tentang skenario tindakan siklus I digunakan untuk memperbaiki pelaksanaan tindakan siklus II.

Dari data diperoleh nilai rata-rata angket pemantauan karakter siswa kelas $\mathrm{X}$ oleh mentee sebesar 65,6 masih dalam kategori sedang. Hasil ini menunjukkan kalau mentee masih kesulitan dalam memantau siswa, ada tujuh mentee masih dikategori sedang dan hanya 1 mentee kategori baik yaitu mentee kelas X MIPA 5. Dengan hasil ini peneliti akan memperbaiki pada siklus II dengan harapan semua mentee kelas $\mathrm{X}$ tidak kesulitan dalam memantau karakter siswa.

Dari data diperoleh nilai rata-rata pemantauan karakter siswa kelas XI oleh mentee sebesar 66,7 masih dalam kategori sedang. Hasil ini menunjukkan mentee masih kesulitan dalam memantau siswa. Lima mentee masih dikategori sedang dan 3 mentee kategori baik yaitu mentee kelas XI MIPA 4, XI MIPA 5 dan XI MIPA 6. Dengan hasil ini peneliti perlu memperbaiki pada siklus II dengan harapan semua mentee kelas XI tidak kesulitan dalam memantau karakter siswa.

Dari data diperoleh nilai rata-rata angket pemantauan karakter siswa kelas XII oleh mentee sebesar 69 masih dalam kategori sedang. Hasil ini menunjukkan kalau mentee masih kesulitan dalam memantau siswa. Dengan hasil ini peneliti dan mentor akan memperbaiki pada siklus II dengan harapan semua mentee kelas XII tidak kesulitan dalam memantau karakter siswa.

Hasil yang diperoleh pada siklus I belum memenuhi indikator keberhasilan karena keberhasilan guru dalam memantau penguatan karakter siswa dengan program afeksi selama PJJ hanya 67,1 dari 80 yang ditargetkan. Penerapan metode mentoring dalam penguatan karakter siswa dengan program afeksi selama PJJ baru mencapai 86,9 dari 90 yang ditargetkan.

\section{Siklus 2}

Sesuai dengan perencanaan setiap siklus dilaksanakan dua kali pertemuan yaitu pertemuan pertama pada hari Selasa, tanggal 16 Februari 2021 dan pertemuan kedua pada hari Rabu, tanggal 24 Februari 2021,

Pertemuan pertama siklus II dilaksanakan pada hari Selasa tanggal 16 Februari 2021 di ruang Lab Seni Budaya SMAN 5 Yogyakarta pukul 13.00 - 15.00 WIB. Pelaksanaan kegiatan yaitu menerapkan tindakan sesuai dengan skenario dan Rencana Pelaksanaan Pembimbingan. Pertemuan dimulai dengan fase mentoring ketiga yaitu fase kemungkinan (enabling). Pada fase ini mentor harus mengatur dengan baik hubungan dengan mentee dan selalu memotivasi kerja mentee, semangat dalam proses pembelajaran dengan monitoring dan evaluasi. Fase kemungkinan mentor memotivasi, membantu dan menjaga hubungan baik dengan mentee, memelihara serta menilai kemajuan terhadap tujuan pemantauan dilaksanakan oleh mentee selama PJJ.

Pendampingan mentoring tetap dilaksanakan oleh mentor dengan memasukkan program penguatan karakter dengan program afeksi ke dalam proses pembelajaran. Mentor memonitor mentee dalam pemantauan karakter dengan masuk dalam group WA kelas. Mentor memberi bimbingan pada saat mentee mengalami kesulitan. Mentee menyampaikan hasil pemantauan penguatan karakter kepada mentor. Melaporkan masalah-masalah yang dihadapi dalam penguatan karakter siswa selama PJJ. Kolaborator mengamati proses pemantauan karakter di kelas dengan program afeksi melalui group WA kelas. Mentor memberi tugas mandiri pada mentee untuk memetakan masalah yang dihadapi dan solusi yang harus disusun. Kolaborator mengamati kegiatan siklus II pertemuan pertama dengan mengisi lembar observasi kegiatan selama pertemuan. Dari hasil pengamatan kolaborator fase ketiga mentoring yaitu fase kemungkinan (enabling) sudah sesuai dengan langkah-langkah pada skenario 
penelitian mentoring. Peneliti, kolaborator dan mentor berkoodinasi untuk pelaksanaan pertemuan kedua dalam rangka untuk penguatan mentoring kepada mentee.

Pertemuan kedua siklus II dilaksanakan pada hari Rabu tanggal 24 Februari 2021 di ruang Lab Seni Budaya SMAN 5 Yogyakarta pukul $13.00-15.00$ WIB. Pelaksanaan kegiatan yaitu menerapkan tindakan sesuai dengan skenario dan Rencana Pelaksanaan Pembimbingan. Pertemuan ini merupakan fase terakhir dari metode mentoring yaitu fase Penutup (coming to closure). Pada fase terakhir adalah fase untuk mengakhiri dalam setiap kegiatan mentoring karena mentoring adalah tujuan yang memprioritaskan pada proses, dan pencapaian hasil kompetensi. Pendampingan mentoring oleh mentor dengan memantau penguatan karakter siswa dengan program afeksi pada masa PJJ dengan menggunakan google form dan $W A$ group dengan metode mentoring.

Mentee memiliki kompetensi memantau penguatan karakter siswa dengan program afeksi. Mentee sudah bisa menggunakan langkahlangkah pemantauan penguatan karakter siswa dengan program afeksi selama PJJ menggunakan google form, group WA dan google class room. Mentee menyampaikan angket karakter siswa kepada siswa ampuannya lewat whatsapp group kelas. Angket karakter siswa dengan program afeksi disampaikan ke siswa secara online menggunakan aplikasi google form. Ada 20 pernyataan yang harus diisi oleh siswa dengan menggunakan skala Likert. Dari 20 pernyataan tersebut terdiri dari lima karakter yang ada dalam program afeksi, yaitu karakter religius, karakter jujur, karakter disiplin, karakter peduli dan karakter toleransi. Masing-masing karakter ada 4 pernyataan sesuai dengan kisi-kisi angket karakter.

Observasi terhadap proses mentoring dilakukan bersamaan dengan pelaksanaan tindakan. Untuk mendapatkan data yang diperlukan kolaborator menggunakan instrumen yang telah disiapkan pada tahap perencanaan. Guna mengukur keberhasilan mentee dalam memantau penguatan karakter siswa dengan program afeksi selama PJJ menggunakan angket lembar observasi pelaksanaan pendampingan dengan metode mentoring untuk mengamati penguatan karakter siswa.

Dalam tahap refleksi, peneliti sebagai salah satu mentor bersama dengan mentor yang lain dan kolaborator melakukan evaluasi tindakan yang telah dilakukan meliputi evaluasi mutu dari tindakan yang dilakukan. Kajian dilakukan untuk mengevaluasi proses dan hasil tindakan yang telah dilakukan serta mengkaji kekurangan atau hambatan. Dari hasil kajian diperoleh kesimpulan kalau mentee sudah bisa melaksanakan tugasnya dengan baik walaupun masih ada beberapa mentee yang harus dibimbing oleh mentor untuk merekap hasil pengamatan terhadap siswa. Sebagai bahan perbaikan kolaborator menyarankan supaya mentor selalu memantau mentee dalam group WA dan selalu bekerjasama. Hasil evaluasi tentang skenario tindakan siklus II digunakan untuk memperbaiki pelaksanaan tindakan siklus II jika belum memenuhi indikator keberhasilan.

Pada akhir siklus II diperoleh data hasil angket pemantauan mentee kelas X, XI dan XII. Hasil siklus II ini sebagai acuan bagi peneliti untuk menghentikan siklus II atau meneruskan dengan siklus III. Apabila sudah memenuhi indikator keberhasilan maka siklus ini akan dihentikan tapi kalau belum memenuhi indikator keberhasilan maka siklus ini akan dilanjutkan dengan siklus III.

Dari data diperoleh nilai rata-rata angket kemantauan karakter siswa kelas X oleh mentee sebesar 83,25 sudah kategori Baik. Hasil ini menunjukkan kalau mentee sudah bisa memantau karakter siswa dengan baik. Hasil ini sudah melebihi indikator keberhasilan 80. Nilai ratarata angket pemantauan karakter siswa kelas XI oleh mentee sebesar 84,25 dalam kategori baik. Hasil ini menunjukkan kalau mentee sudah memantau karakter siswa dengan baik. Hasil ini sudah melebihi indikator keberhasilan 80. Nilai rata-rata angket kemantauan karakter siswa kelas XII oleh mentee sebesar $86 \%$ sudah kategori amat baik. Hasil ini menunjukkan kalau mentee dapat memantau karakter siswa dengan baik. Dengan hasil ini sudah memenuhi indikator keberhasilan

Dari data angket yang diisi oleh mentee dapat disimpulkan bahwa tingkat pemahaman mentee terhadap penggunaan metode mentoring dalam pemantauan karakter siswa berbasis program afeksi selama PJJ dengan nilai rata-rata 92.45 kategori amat baik. Dengan hasil ini sudah memenuhi indikator keberhasilan yaitu penerapan metode mentoring dalam penguatan karakter siswa dengan program afeksi selama PJJ 92,45 diterima oleh guru-guru SMAN 5 Yogyakarta sudah melebihi indikator 90 sehingga siklus berikutnya tidak diteruskan.

\section{Pembahasan}

Untuk menentukan keberhasilan penelitian ini, data hasil penelitian dianalisis mengacu pada tujuan penelitian yang kemudian dituangkan dalam kriteria keberhasilan penelitian. Keberhasilan diukur dari peningkatan 
kompetensi guru dalam menerapkan model mentoring dalam memantau karakter siswa berbasis program afeksi selama PJJ dan peningkatan kompetensi guru dalam memantau karakter siswa dikelas selama PJJ.

\section{Kompetensi guru dalam memantau penguatan karakter siswa berbasis program afeksi selama PJJ}

Dari hasil angket pemantauan karakter siswa kelas X oleh mentee diperoleh data siklus 1 dan siklus 2 seperti pada gambar 1 di bawah ini. Ada peningkatan dari siklus I dengan nilai ratarata 65,6 pada siklus II dengan nilai 83,25.

Pemantauan Karakter Siswa Kelas $\mathrm{X}$ oleh Mentee

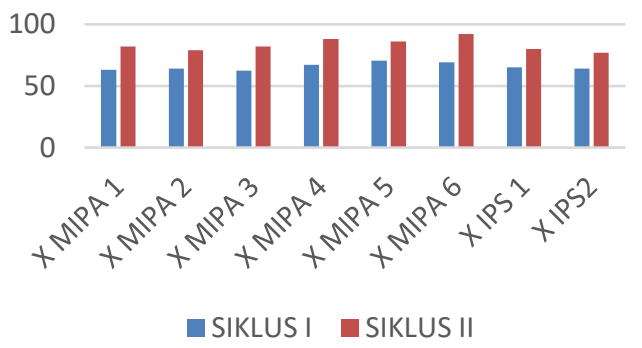

Gambar 1. Diagram batang pemantauan karakter siswa kelas X oleh mentee

Dari hasil angket pemantauan karakter siswa kelas XI oleh mentee diperoleh data siklus 1 dan siklus 2 seperti pada gambar 2 di bawah ini. Ada peningkatan dari siklus I dengan nilai rata-rata 66,7 pada siklus II dengan nilai 84,25.

Pemantauan Karakter Siswa Kelas XI oleh mentee

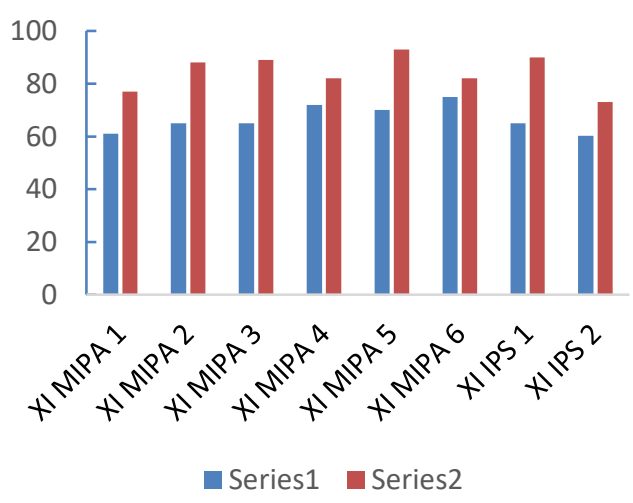

Gambar 2. Diagram batang pemantauan karakter siswa kelas XI oleh mentee

Dari hasil angket pemantauan karakter siswa kelas XII diperoleh data siklus 1 dan siklus 2 seperti pada gambar 3 di bawah ini. Ada peningkatan dari siklus I dengan nilai rata-rata 69 pada siklus II dengan nilai 86 .

\section{Pemantauan karakter siswa kelas XII oleh mentee}

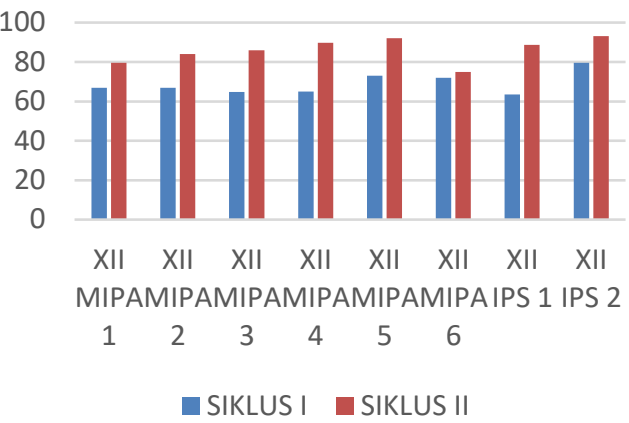

Gambar 3. Diagram batang pemantauan karakter siswa kelas XII oleh mentee

\section{Penerapan metode mentoring dalam pemantauan karakter siswa berbasis program afeksi selama PJJ}

Dari hasil angket kompetensi mentee kelas X dalam memahami metode mentoring diperoleh data siklus 1 dan siklus 2 seperti pada gambar 4 di bawah ini. Ada peningkatan dari siklus I dengan nilai rata-rata 80,25 pada siklus II dengan nilai 89,6 .

Kompetensi Mentee kelas X dalam memahami metode mentoring

$$
\text { Siklus } 1 \quad \text { Siklus2 }
$$

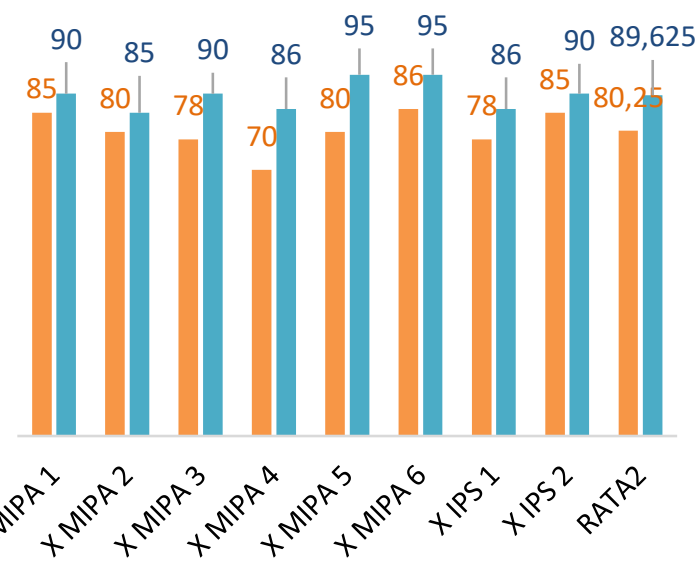

Gambar 4. Diagram batang Kompetensi Mentee kelas X dalam memahami metode mentoring

Dari hasil angket kompetensi mentee dalam pemantauan karakter siswa kelas XI diperoleh data siklus 1 dan siklus 2 seperti pada gambar 5 di bawah ini. Ada peningkatan dari siklus I dengan nilai rata-rata 86,13 pada siklus II dengan nilai 91,19 . 
Kompetensi mentee dalam Pemantauan Karakter Siswa kelas XI
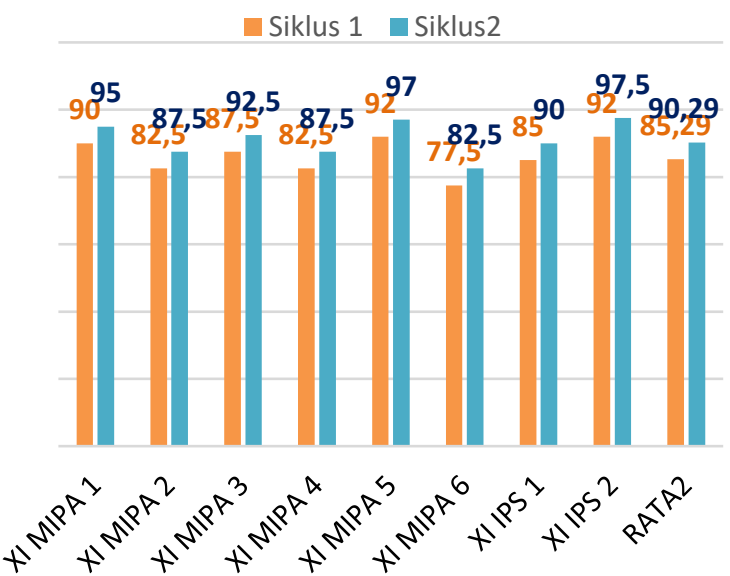

Gambar 5. Diagram Kompetensi Mentee dalam Pemantauan Karakter Siswa Kelas XI

Dari hasil angket kompetensi mentee dalam pemantauan karakter siswa kelas XII diperoleh data siklus 1 dan siklus 2 seperti pada gambar 6 di bawah ini. Ada peningkatan dari siklus I dengan nilai rata-rata 94,44 pada siklus II dengan nilai 96,56 .

Untuk menentukan keberhasilan penelitian, data hasil penelitian dianalisis mengacu pada tujuan penelitian yang kemudian dituangkan dalam kriteria keberhasilan penelitian.

Kemampuan mentee dalam memahami metode mentoring mengalami peningkatan dari siklus I sebesar 86 kategori amat baik menjadi 92,5 pada siklus II dengan kategori amat baik.

Kompetensi guru dalam memantau penguatan karakter siswa berbasis program afeksi selama PJJ, dari hasil angket kompetensi mentee dalam pemantauan karakter siswa diperoleh data siklus 1 dan siklus 2 seperti pada tabel 1 di bawah ini. Ada peningkatan dari siklus I dengan nilai 67,1 dengan kategori cukup dan pada siklus II dengan nilai 84,5 dengan kategori baik.
Kompetensi Mentee dalam

Pemantauan Karakter siswa kelas XII

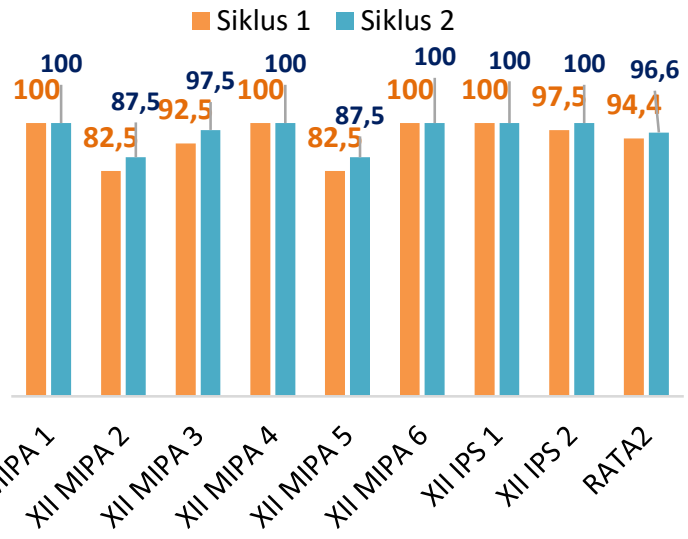

Gambar 6. Diagram batang Kompetensi Mentee dalam Pemantauan Karakter Siswa Kelas XII

Kemampuan mentor dalam memahami ketugasan mentoring dengan kategori amat baik, seperti pada gambar 7 di bawah ini. Ada peningkatan dari siklus I 88,9 menjadi 93 pada siklus II.

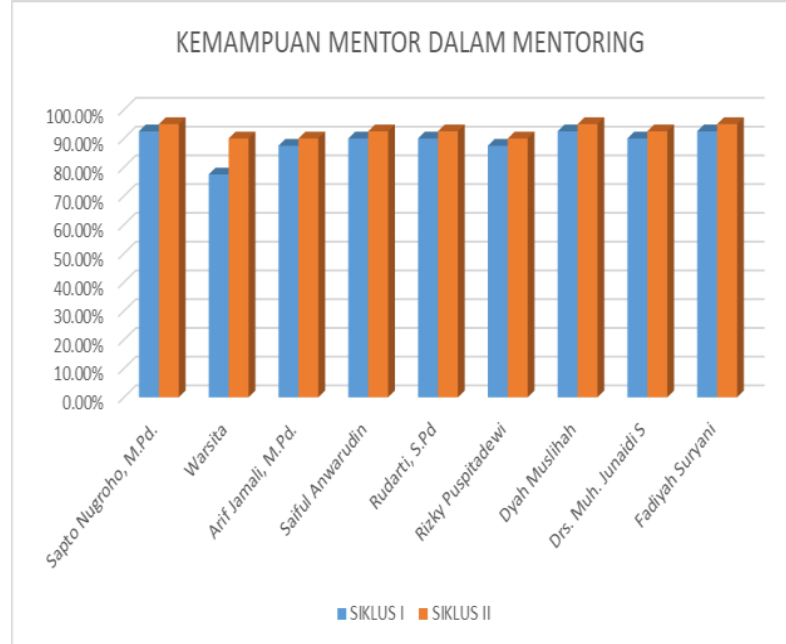

Gambar 7. Diagram kemampuan mentor memahami metode mentoring

Tabel 1. Hasil angket pemantauan mentee terhadap siswa SMAN 5 Yogyakarta

\begin{tabular}{|c|c|c|c|c|c|c|}
\hline \multirow{2}{*}{ No } & \multirow{2}{*}{ Kelas } & \multicolumn{2}{|c|}{ Siklus 1} & \multicolumn{2}{|c|}{ Siklus 2} & \multirow{2}{*}{ Rerata } \\
\hline & & Nilai & Kategori & Nilai & Kategori & \\
\hline 1. & X MIPA 1 & 63 & Cukup & 82 & Baik & 72,5 \\
\hline 2. & X MIPA 2 & 64 & Cukup & 79 & Baik & 71,5 \\
\hline 3. & X MIPA 3 & 62,5 & Cukup & 82 & Baik & 72,25 \\
\hline 4. & X MIPA 4 & 67 & Cukup & 88 & Amat baik & 77,5 \\
\hline 5. & X MIPA 5 & 70,5 & Baik & 86 & Amat baik & 78,25 \\
\hline 6. & X MIPA 6 & 69 & Cukup & 92 & Amat baik & 80,5 \\
\hline 7. & X IPS 1 & 65 & Cukup & 80 & Baik & 72,5 \\
\hline 8. & X IPS 2 & 64 & Cukup & 77 & Baik & 70,5 \\
\hline
\end{tabular}




\begin{tabular}{|c|c|c|c|c|c|c|}
\hline 9. & XI MIPA 1 & 61 & Cukup & 77 & Baik & 69 \\
\hline 10. & XI MIPA 2 & 65 & Cukup & 88 & Amat baik & 76,5 \\
\hline 11. & XI MIPA 3 & 65 & Cukup & 89 & Amat baik & 77 \\
\hline 12. & XI MIPA 4 & 72 & Baik & 82 & Baik & 77 \\
\hline 13. & XI MIPA 5 & 70 & Baik & 93 & Amat baik & 81,5 \\
\hline 14. & XI MIPA 6 & 75 & Baik & 82 & Baik & 78,5 \\
\hline 15. & XI IPS 1 & 65 & Cukup & 90 & Amat baik & 77,5 \\
\hline 16. & XI IPS 2 & 60,2 & Cukup & 73 & Baik & 66,6 \\
\hline 17. & XII MIPA1 & 67 & Cukup & 79,5 & Baik & 73,25 \\
\hline 18. & XII MIPA2 & 67 & Cukup & 84 & Baik & 75,5 \\
\hline 19. & XII MIPA3 & 64,8 & Cukup & 86 & Amat baik & 75,4 \\
\hline 20. & XII MIPA4 & 65 & Cukup & 89,7 & Amat baik & 77,35 \\
\hline 21. & XII MIPA5 & 73 & Baik & 92 & Amat baik & 82,5 \\
\hline 22. & XII MIPA6 & 72 & Baik & 75 & Baik & 73,5 \\
\hline 23. & XII IPS 1 & 63,6 & Cukup & 88,6 & Amat baik & 76,1 \\
\hline 24. & XII IPS 2 & 79,5 & Baik & 93,2 & Amat baik & 86,35 \\
\hline & Rerata & 67,1 & Cukup & 84,5 & Baik & 75,8 \\
\hline
\end{tabular}

Kompetensi guru dalam memantau penguatan karakter siswa berbasis program afeksi selama PJJ. Dari hasil angket kompetensi mentee dalam pemantauan karakter siswa diperoleh data siklus 1 dan siklus 2 . Ada peningkatan dari siklus I dengan nilai 67,1 pada siklus II dengan nilai 84,5. Angket karakter siswa yang disampaikan mentee lewat google form. Angket karakter yang diisi oleh siswa menunjukkan bahwa siswa sangat peduli terhadap karakter yang ada didalam program afeksi. Dari 833 siswa SMA N 5 Yogyakarta ada 829 siswa yang mengisi angket karakter program afeksi, diperoleh data seperti pada gambar 8 di bawah ini.

Dari data gambar 8 dapat disimpulkan bahwa siswa dengan karakter kategori amat baik sebanyak 57\%, kategori baik 40\%, kategori cukup

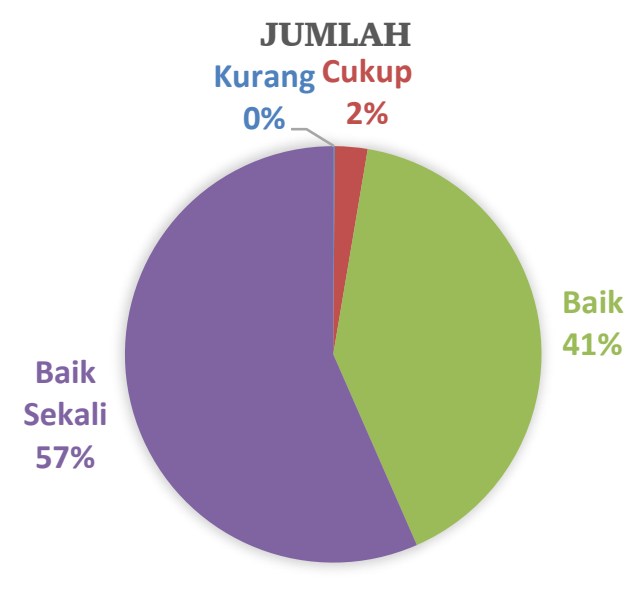

Gambar 8. Hasil angket karakter siswa SMA N 5 Yogyakarta $2 \%$ dan kurang $0 \%$. Analisa angket karakter siswa program afeksi seperti pada tabel 2 di bawah ini.

Tabel 2. Nilai Karakter Siswa

\begin{tabular}{cllc}
\hline No & Karakter & \multicolumn{1}{c}{ Indikator } & Nilai \\
\hline 1 & Religius & Berdo'a sebelum pelajaran & 94,57 \\
& & Berdo'a sesudah pelajaran & 84,05 \\
& & Membaca Kitab Suci & 88,84 \\
& & Sholat (muslim) & 95,21 \\
& & Pesrsekutuan Do'a siang dan sore (Kristiani) & \\
\hline 2 & \multirow{2}{*}{ Jujur } & Tidak mencotek saat ulangan & 95,15 \\
& & Mengembalikan barang yang bukan hak saya & 100 \\
& & Berkata jujur & 90,32 \\
& & Jujur dalam mengerjakan soal & 87,73 \\
\hline 3 & Disiplin & Mengikuti pelajaran dengan tertib & 87,12 \\
& & Hadir tepat waktu pada saat pelajaran & 87,73 \\
& & Mengunakan seragam sekolah sesuai aturan & 75,99 \\
& & Mentaati aturan sekolah & 87,97 \\
\hline
\end{tabular}




\begin{tabular}{cclc}
\hline 4 & Peduli & Bangga dengan hasil sendiri & 95,81 \\
& & Senang berbagi ilmu & 100 \\
& & Membuang sampah pada tempat & 97,59 \\
& & Selalu membantu orang tua & 94,87 \\
\hline 5 & \multirow{2}{*}{ Toleransi } & Menghargai pendapat teman & 98,61 \\
& & Menerima saran dan kritik dengan lapang dada & 94,06 \\
& & 89,81 \\
& & Senang bekerja dengan kelompok & 86,64 \\
& & bertegur sapa dengan semua guru dan teman saat bertemu \\
& walaupun lewat group WA, sosial media lain & \\
\hline & Rata-rata & 91,65 \\
\hline
\end{tabular}

Dari hasil tabel 2 menunjukkan siswa SMA N 5 Yogyakarta mempunyai karakter amat baik dengan rata-rata hasil 91,65. Hasil penelitian ini menujnjukkan bahwa mentoring memfasilitasi hubungan antara mentor dan mentee sehingga memberikan kesempatan untuk berdiskusi yang menghasilkan refleksi dalam pemanataun karakter siswa selama masa PJJ. Mentoring terbukti memberikan kesempatan komunikasi saling menguntungkan untuk meraih tujuan bersama. Hasil penelitian ini sejalan dengan pendapat Edi Harapan dan Syawani Ahmad (2014: 12).

\section{Simpulan dan Saran}

Dari hasil penelitian yang diperoleh dapat ditarik kesimpulan sebagai berikut: pertama, metode mentoring terbukti signifikan untuk meningkatkan kompetensi guru (mentee) dalam memantau karakter siswa berbasis program afeksi selama PJJ, dengan hasil pada siklus I mencapai $67,1 \%$ dan mengalami peningkatan pada siklus II $84,5 \%$. Hasil ini sudah melebihi dari indikator keberhasilan dari $80 \%$. Selain peningkatan kompetensi mentee, diiringi pula dengan peningkatan kompetensi mentee dalam melaksanakan mentoring pemantauan karakter siswa berbasis program afeksi selama PJJ yaitu pada Siklus 1 menunjukkan capaiaan rata-rata 86, sedangkan Siklus II meningkat menjadi 92,5. Capaian ini telah melampaui batas indikator keberhasilan yang ditetapkan yaitu 90 .

Kedua, penerapan metode mentoring dilakukan dengan tahapan yang jelas dengan menempatkan mentee sebagai mitra. Mentor memberi mengajak berdiskusi, melakukan refleksi bersama, memberikan saran dan kritik membangun, membiasakan keterbukaan, kepercayaan, dan penghargaan. Mentee diberikan kesempatan untuk bertanya atau menyampaikan pendapat dalam suasana normal dan nyaman.

\section{Daftar Pustaka}

Arikunto, Suharsimi. (2010). Prosedur Penelitian Suatu Pendekatan Praktek. Jakarta: PT. Rineka Cipta.

Bambang Irianto. (2003). Kurikulum Berbasis Kompetensi Salah satu Solusi Dalam Memenuhi Tuntutan Global dan Lokal (makalah), Bandung: ITB.

Berkowitz, M.W. \& Bier, M.C. (2005). What Works In CharacterEducation: A ResearchDriven Guide for Educators, Washington DC: Univesity of Missouri-St Louis.

DuBois, D.L., dan Karcher, M.J. (2005). Handbook of Youth Mentoring. California: Sage Publishing.

Edi Harapan dan Syawani Ahmad. (2014). Komunikasi Antarpribadi: Perilaku Insani dalam Organisasi Pendidikanll. Jakarta: Raja Grafindo Persada.

Lickona, Thomas. (1997). Educating for Character; How our schools can respect and responsibility. New York: Bantam.

Poerwadarminta, (2007). Kamus Umum Bahasa Indonesia. Jakarta: Balai Pustaka.

Rohinah M. Noor, MA. (2012). The Hidden Curriculum: Membangun KarakterMelalui Kegiatan Ekstrakurikuler. Yogyakarta: Insan Madani.

Siswoyo. (1992). Analisis Data Kualitatif. Jakarta: UI-Press.

Sudarman Danim. (2011). Pengembangan Profesi Guru: Dari Pra Jabatan Induksi ke Profesional Madani. Jakarta: Kencana Prenada Media Group.

Zubaedi. (2011). Desain Pendidikan Karakter Konsepsi dan Aplikasinya dalam Lembaga Pendidikan. Jakarta: Prenada Media Group. 